\title{
Behavioral Aspects in Obligatory Reports of Public Hospitals in Poland
}

\author{
Aleksandra Szewieczek, Marzena Strojek-Filus \\ University of Economics in Katowice, Katowice, Poland
}

\begin{abstract}
The health care sector is the most difficult one to manage and control. Special units in this field are public hospitals which are required to prepare a lot of reports to various institutions, including the ownership body. The paper focuses on two issues. The first is the presence of behavioral factors in the reporting of public hospitals in Poland to the ownership bodies. This article aims to indicate the thematic areas of specific reports, most affected by behavioral factors and explain the causes and consequences of their occurrence. The second issue is the analysis of the legal status of obligatory reporting of public hospitals. Participants of the conducted research, due to their specific ownership and political and social position, were public hospitals in Poland. The paper uses the research methods of the meta-analysis of the literature, legal acts in Poland and empirical materials, and also the methods of synthesis, observation, and deduction. Data analysis focused on specific sample of reports issued by Polish public hospitals for their ownership body. The research shows that hospitals draw up a tremendous number of often thematically overlapping and redundant reports addressed to different institutions in different time periods. It is a consequence of legal regulations failing to streamline the reporting of the health care sector institutions, in particular public hospitals. The paper points to the large number of legal instruments that contain imprecise requirements resulting from the complex and obscure forms of control of public funds allocation in this sector. There are many behavioral factors that shape some fields of public hospitals' reports, for example, interpersonal relationships, egoism, private financial interests, strengthening of the employment status and professional position, and professional competences. There is considerable freedom in the reporting process fulfilled by public hospitals in Poland for their ownership body. It causes strong consequences, like poor-quality data, duplication of information, and its chaos, as well as high costs of obtaining information. Reporting system of financial and non-financial data of public hospitals in Poland is dysfunctional.
\end{abstract}

Keywords: public hospitals, financial and non-financial reports, finance in health care sector, reliability, ownership body, behaviorism

\section{Introduction}

Setting directions for health care policy, the proper use of public and private funds in health care, and finally the management of health care institutions all require proper, useful, objective, accurate, and reliable

\footnotetext{
Aleksandra Szewieczek, Ph.D., Faculty of Finance and Insurance, Department of Accounting, University of Economics in Katowice, Katowice, Poland.

Marzena Strojek-Filus, associate professor, Faculty of Finance and Insurance, Department of Accounting, University of Economics in Katowice, Katowice, Poland.

Correspondence concerning this article should be addressed to Aleksandra Szewieczek, University of Economics in Katowice, Department of Accounting, ul. Bogucicka 3, 40-287 Katowice, Poland.
} 
information. The information in health care is generated at various management levels-macro, meso, and micro. The micro-level provides access to the most detailed data, the most closely related to patients. The data, in a large part, come from the reporting system of health care entities and include financial and non-financial area. This information is reported by public and non-public health care entities, although to a much wider range by entities with the public ownership structure. This is due to the strong pressure of founding bodies on subordinate public entities, which have to protect health and life of the residents at least within their territory. The organization and supervision of these tasks is delegated by the territorial self-government. Meanwhile, private entities are primarily driven by profit maximization and achieving the investor intended rate of return on invested capital, which at the same time appropriately shapes the directions of their reporting.

The specific situation of the ownership of public hospitals in Poland, as well as dependency from the founding body on management staffing decisions in these entities, coupled with their political character, shape certain behaviors in the report preparation process of public hospitals. The reporting of public hospitals in Poland is characterized by a great thematic diversity, large dispersion, and a high level of detail. Thematic duplication and lack of inter-institutional communication can also be indicated in this field. The reporting is also regulated by many legal acts, both sectoral and general.

This article aims to identify and analyze behavioral areas of obligatory reporting of public hospitals in Poland in terms of their relationship with the founding body. The equal aim is to conduct a detailed thematic and subjective classification of the reporting of public hospitals based on qualitative analysis of the regulatory sphere.

There have been formulated the following detailed research questions:

(1) Which thematic areas of reports from public hospitals for the founding (ownership) body are most affected by behavioral factors?

(2) Which behavioral factors are mostly visible in the qualitative analysis of the reports produced by those entities for the founding (ownership) body?

(3) What irregularities in the communication of public hospitals with other institutions by the means of reports can be identified in respect of the existing legislation?

The paper uses the research methods of the meta-analysis of the literature, legal acts currently in force in Poland, and empirical materials. The synthesis of partial results was carried out in order to draw final conclusions. The method of observation and deduction for the study of content of sample the reports prepared for founding bodies by health care units was also used. Due to the multi-faceted aspect of survey data, the study focused on public hospitals.

The paper is original work, dealing with behavioral factors related to the relationship between the ownership body and the subordinate unit and influencing the scope of selected elements of the reports of public hospitals. The result of such actions could be intentional creation of the desired-in relations with the ownership body — picture of the financial and non-financial situation of these units.

\section{The Characteristics of the Relationship Between Public Hospitals and Their Ownership Body in Poland}

The health care sector is one of the most difficult areas of the state activity in terms of coordination and control. It is also a sector where the biggest changes have occurred in recent years. Reforms in the health care services were carried out in many European countries during this period, in particular regarding the functioning of hospitals (Pettersen \& Solstad, 2015). Poland is a country where changes in health care are phased in and the 
authorities' lack of the vision of the target system can be noticed. The act of the highest order in Poland - the Constitution ${ }^{1}$ - provides that the state has an obligation to ensure equal implementation of the health care needs of citizens within the public funds intended for this purpose (Constitution; Frączkiewicz-Wronka, 2001). However, the role and relationship between the private and public health care sector become problematic in this context. This issue particularly focuses on public hospitals. It is worth noting that in Europe there are preferred solutions based on covering most of the costs of treating patients with public funds (Dziubińska, Janus, Kostrubiec, Sroka, \& Szczęśniak, 2014).

The insurance model of health care financing has been implemented in Poland since 1999, in which the predominant source of funding is the income from the universal health insurance premiums, paid by working people and other groups of society. The allocation of income between health care providers is associated with the actual delivery of health services (Szewieczek, 2014). The supervision of the health care system and the implementation of health care policy in Poland belongs to the Ministry of Health. These obligations, to a slightly lesser extent, are also enforced by lower levels of public authority-at a territorial level and self-government level. In Poland, the following major participants in the health care system can be indicated on the basis of existing legislation:

- beneficiaries (patients);

- public payer, managing the public funds of heath care financing - the National Health Fund;

- health care service providers (medical entities, which could include entrepreneurs, independent public health care institutions, budgetary units, research institutes, foundations, churches units, associations, pharmacies, and others);

- inspection and supervision authorities (the State Sanitary Inspection, the Patient Ombudsman, the State Pharmaceutical Inspection, regional governors, etc.).

The National Health Fund plays a dominant role of a payer for medical services. It is basically the only source of funding for health care services in public hospitals. Since these hospitals cannot charge patients' fees for health care services that are publicly funded. Additional sources are the funds of the Ministry of Health for highly specialized health care services or funds from a territorial self-government, including the implementation of health programs. Another source is the individual insurance, within which the cost of the provided health care services is paid by the insurer or a private fee.

In Poland, from the point of view of the founding body, it can identify the following types of hospitals (Krzeczewski, 2014):

- public hospitals:

- subject to territorial self-government units;

- sectoral, subject to, e.g., military sector;

- university, subject to the authorities of public medical universities;

- non-public hospitals operating on the basis of private capital.

Taking into account the level of a territorial self-government unit as the founding body, the followings can be distinguished:

- regional (voivodeship) hospitals;

- district hospitals (Polish: powiat);

- municipality hospitals (Polish: gmina).

\footnotetext{
${ }^{1}$ It is published by the Polish Constitution (1997, April) in Journal of Laws 78, item 483.
} 
As far as the aim of this paper is concerned, the relationship between the public sector units (territorial self-government, public medical university, and so-called sectoral ministries) and subordinate to them hospitals is particularly important. It should be emphasized that these units create, merge, and close hospitals and equip them with initial assets. Moreover, under certain conditions, they can provide additional funds, mainly for investment activities. The founding body also decides on the selection of the head of the hospital and the statutes of the hospital as well as executes the ownership supervision — ownership control (for that reason, the founding body will be interchangeably referred to as the ownership body in this paper). Therefore, the management board of the public hospital is supervised directly by the ownership body and is appraised on the basis of effectiveness and performance. This relationship may affect attitudes of hospital managers as to obtain the approval of supervisors and positive image of the exercised function. In the management of a public hospital-the ownership body relationship the "political burden" may also be important and thus the political preferences of representatives of public ownership bodies. This may affect the appraisal of the performance of the hospital board.

This particular position of public hospitals reporting to public institutions can trigger a series of "defense" reactions on the part of management boards with regard to reports issued by them. They can form the basis of behavioral problems in the reporting for the ownership bodies. On one hand, the hospital board needs to reconcile actions of physicians, guided by their own interests (frequency and scope of tests performed, length of hospital stay), and on the other hand, the interests of the owners. This relationship can be associated with the agency theory both in the doctor-patient relationship and in the hospital-ownership body relationship (Morris, Devlin, \& Parkin, 2011). In public hospitals, there are processes of fulfilling the tasks assigned to their ownership bodies by the legal regulations. The followings can be mentioned in this respect: the provision of health care services, education process of health professionals, or scientific research (university hospitals). In this regard, the influence of the owner on the management decision-making processes of subordinate hospitals can be noticed. This influence of the owner may be strictly concerned with the quality, especially reliability, of financial and non-financial reports prepared by hospitals. The reliability is fundamental and the most desirable feature of reports (Strojek-Filus, Szewieczek, \& Maruszewska, 2015).

\section{Review of Research on Behavioral Aspects of the Reporting of Public Hospitals}

The research field of the impact of the relationship between public hospitals and their owners, in the aspect of behavioral phenomenon in the reporting process, has not previously been studied in detail. In Poland, the studies on the information generated by public hospitals and its use for the purposes of the founding body are carried out (Hass-Symotiuk, 2010). They are the only such broad studies on the reporting of public hospitals and sets of information generated by them in Poland. Although they do not concern behaviorism, they generally emphasize the possibility of significant influence of supervisory bodies on the activities of subordinate units, also by the means of a special appraisal of their leaderships. The results of studies highlighted the important part played by founding bodies in determining investment policy, control of mainly financial management, and management of current assets (including medical). Among the main reporting areas, clearly on the first and second positions are listed the financial data and information about the provision of health services.

Krzeczewski (2014) conducted a study on the impact of the founding body on the financial efficiency of hospitals in the Lodz region. The author of the study revealed differences in the financial effectiveness between hospitals belonging to the territorial self-government units and non-public hospitals. Better results are achieved by non-public hospitals in terms of net income, operating profitability, and productivity of assets. In turn, 
public hospitals show better liquidity. The general conclusion of the study confirmed the influence of the founding body on the quality of management in hospitals.

Extensive research on a national scale was carried out in public hospitals in Poland in 2005-2006 by a team led by Holly and Suchecka (2009). Although the study did not directly concern the hospital management board - ownership body relationship in terms of behavioral aspects, but it reviled a lot of negative mechanisms of functioning of hospitals, not shown in the reports.

A study conducted in Norway was devoted to the behavior analysis of top managers at various levels in local hospitals in terms of exercising vertical and horizontal control (Pettersen \& Solstad, 2015). Disrupted communications with the regional authorities and consequently errors in the distribution of financial resources among the hospitals due to lack of proper management control of a horizontal nature and lack of support from the supervisory body to provide information useful for management were demonstrated. The researchers pointed out that the local authority does not contribute to creating a financial and operational analysis, but at the same time, the hospitals did not see the need to involve this authority in the process. The study also identified a lack of adequate financial resources of local authorities to support in this respect every subordinated health unit, and its failure to participate in the dissemination of management information among subordinate units, both for benchmark purposes, as well as for the exchange of good management practices. In a study conducted by Christensen, Laegreid, and Stigen (2006), behavioral factors of adopted solutions for the management system of public hospitals in Norway as part of a reform in this sector were stressed. The authors emphasize, inter alia, the fact that new solutions account for such aspects as environmental factors, relationships, and cultural traditions. This proves that the behavioral trend in the management of public hospitals is increasingly emphasized, including the impact of ownership body on hospitals' activities. Studies carried out in the USA by McCleary, Rivers, and Schneller (2006) have shown that behavioral factors are important in creating corporate structures among business entities operating in the health sector. The relationship between entrepreneurs as owners and managers of capital is even more important. Particularly, factors, such as motivation, time, measures taken, risk, and consequences of actions, are pivotal in this respect.

Frolich, Talavera, and Adams Dudley (2007) analyzed the implementation of the P4P (pay-for-performance) and PR (public reporting) strategies in the health care system. These strategies are based upon the use of carefully selected incentives to improve the management and reporting. They have been adopted in the health care sector from other sectors of the economy and are widespread in many countries, for example, in the USA, Canada, and Australia. The authors developed a model based on P4P and PR specially adopted to the needs of the health sector. They found that a lot of economic and psychological factors affect the behavior of participants of this sphere. Their reaction to stimuli is one of the determinants of the entire system. The authors used, inter alia, the theory of financial incentives to achieve the desired behavior. Another group of stimuli consists of those relating to reputation, psychological aspects. It is important that traits, such as motivation, professionalism, and altruism, may affect the response to stimuli. Thus, the selection of the stimuli must be carried out in such a way as to minimize such impact.

The behavioral aspects of medical error reporting for ownership body were shown by Porto and Lauve (2006). Although the research focuses on the issue of developing guidelines and procedures for medical treatment participants, the authors also mentioned the importance of drawing up relevant reports in the context of such factors as interpersonal relationships in the hospital and avoidance of disclosing information about errors and their causes. In that respect, utilizing the research carried out by Porto and Lauve (2006), the aspects of shaping 
reporting items in a subjective manner in other reports drawn up by public hospitals can be indicated, so as to achieve the desired image of the unit and management effects, evaluated then by the ownership body.

In an attempt to identify the behavioral factors influencing the reporting by public hospitals, one should take into account individual factors shaping the behavior of the top management. This study, however, mainly focuses on the hospital management-subordinate staff relationship. Kent (2006) distinguished five behavioral types of leaders in health care units. These types have been identified from the perspective of subordinates, not superiors, but they may give rise to further study on the hospital management — ownership body relationship, and can be defined as:

- visionary-focusing on creating a vision of the future, a positive image of current activities, and motivation for action through visualization of achievements;

- collective success-emphasizing the success of collective work aimed at teamwork, open, and communicative for other employees;

- communicative - aimed at the exchange of experiences, cooperation, and sharing of ideas and knowledge, also by conflicts;

- professional leader-has trust from subordinates, faith in their skills and competences, predictable and centered, keeping the opinion, and restraining emotions;

- caring - noticing efforts and work of others and appreciating the efforts of subordinates.

These types of the superior who is simultaneously a subordinate in relation to the founding body may determine certain behavioral aspects in the reporting relationship process of his/her own achievements in the management of the hospital. Similarly to the indicated types, the determinants of attitudes and behaviorism (or lack of them) in relations with a supervisor can be identified, based on:

- focusing on strategy;

- identifying the causes of success and failure in the work of the team (avoiding single-responsibility);

- pursuing operational cooperation and substantive support of the founding body in the management of the hospital;

- demonstrating the features of a professional manager who bears all the consequences associated with the managing of the whole hospital;

- a significant work commitment of their subordinate staff with the empowerment in decision-making and, consequently, responsibility, but also with an understanding of mistakes, and crisis management in relations with the ownership body.

Krivokapic (2014) also conducted a study in this respect. The author of the study indicated, on the example of Montenegro, that in transition countries, managing bodies in health care does not significantly impact the motivation of subordinates and is assessed on average by them. At the same time, he emphasized the role of leaders in health care as mediators in the relationship with different audiences.

\section{Obligatory Reporting in Public Hospitals in Poland}

An obligatory reporting public hospital in Poland is of multifarious nature, as it applies to non-financial and financial areas. Additionally, as part of the former, the material scope includes health care services, the use of resources, and other reports. Repeatedly reports take a mixed form, containing information about incurred costs, expenses, earned income, as well as the use of resources, the number of employees, and delivered health care services (Table 1). 
Table 1

Aspects of Public Hospitals Reports

\begin{tabular}{|l|l|}
\hline \multirow{2}{*}{ Reports area } & The material scope \\
\hline \multirow{2}{*}{ Non-financial } & Revenues, costs, and incomes \\
\cline { 2 - 2 } & Expenses, investments, etc. \\
\hline Mixed & Non-financial operating results (health care services) \\
\cline { 2 - 2 } & Resources utilization (fixed assets, human resources, medical equipment, and others) \\
\hline
\end{tabular}

Considerable variations in the scope of reporting are due to a variety of legal acts and other guidelines affecting this area, including the provisions of the accounting and tax law, regulations on official statistics, financing of health care services from public funds, corporate governance, and other regulations and guidelines. It should be added that those regulations do not always directly determine the reporting scope and formulas (for example, on the founding body supervision in the public sector). They can also apply to the same generic reports. In addition to the diverse reporting field, the reports are presented in a multi-directorial manner. This stems not only from the legal regulations, but also the legal form of the medical entity and the managerial consequences coming from this fact, except that in the case of private entities, the obligations are smaller. Among the recipients of the reporting information from health care entities, the institutions from the macro-, meso-, and micro-management levels of health care sector, and health care entities can be indicated (Table 2).

Table 2

Health Care Entities' Reports Stakeholders

\begin{tabular}{|c|}
\hline Ministry of Health \\
\hline Founding Body/Owners \\
\hline Patients \\
\hline National Health Fund \\
\hline Central Statistical Office \\
\hline Government \\
\hline Local Government \\
\hline Bank, Suppliers \\
\hline Tax Office \\
\hline Others \\
\hline
\end{tabular}

Taking into account the multi-directionality and diversity of obligatory reporting of public hospitals in Poland, having also regarded to incomplete formalism in terms of content, format, and timing of its implementation, the authors of the paper have reviewed and next provided the synthesis of the processes implemented in this field in Polish health care system (Table 3).

Public hospitals in Poland prepare financial statements and other reports (including statistics). Not all of these reports are compiled solely by the health care entity. The decisive factor may be the legal form of activity, scope of provided health services, type of founding body, or the requirements of the conducted statistical survey program. In this field, reports submitted to the founding body (the owner representing the public sector at various levels) are clearly distinguished from the others in terms of the scope of standardization. It has only been determined generally that some of these reports should be prepared (financial and investment plan), while preparing other is related to the performance of supervisory functions in the public sector and for the most part not subject to specific regulations, apart from stating the general area of the reporting, which they should concern (Table 4). There are no additional legal regulations in this regard. These reports and the frequency of 
their preparation are freely determined by the ownership entity. This leads to a strong impact of human factors, behavioral determinants in this area that shape specific and desired image a public health care entity. Causative agents of such actions are largely relationships that exist between the top managers of health care entity and its owner - the founding body. Behavioral factors in the development of selected reporting items can occur to the greatest extent in this area.

Table 3

Types of Obligatory Reports Issued by Public Health Care Entities in Poland

\begin{tabular}{|c|c|c|c|c|}
\hline Report's type/name & Report's field & Law regulation* & Scope of normalization & Stakeholder \\
\hline \multicolumn{5}{|l|}{ FINANCIAL REPORTS } \\
\hline Annual financial report & $\begin{array}{l}\text { Income, costs, financial } \\
\text { results, assets, liabilities, } \\
\text { capital, and cash }\end{array}$ & The act on accounting & $\begin{array}{l}\text { Strictly regulated, certain } \\
\text { patterns, and principles } \\
\text { of preparation }\end{array}$ & $\begin{array}{l}\text { Owner/founding body, } \\
\text { contractor, tax office, } \\
\text { and registry court }\end{array}$ \\
\hline $\begin{array}{l}\text { Statement of income and } \\
\text { costs, and profit }\end{array}$ & Income, costs, and profit & $\begin{array}{l}\text { The act on income tax } \\
\text { from natural persons }\end{array}$ & $\begin{array}{l}\text { Strictly regulated, certain } \\
\text { patterns, and principles } \\
\text { of preparation }\end{array}$ & Owner, tax office \\
\hline $\begin{array}{l}\text { MZ-03, MZ-BFA } \\
\text { F-01/I-01, F-02 }\end{array}$ & $\begin{array}{l}\text { Similar to annual } \\
\text { financial report }\end{array}$ & $\begin{array}{l}\text { The act on public } \\
\text { statistic; } \\
\text { regulation on } \\
\text { determining outlines of } \\
\text { reporting forms (...), } \\
\text { issued annually }\end{array}$ & $\begin{array}{l}\text { Established models and } \\
\text { deadlines for } \\
\text { preparation, selective } \\
\text { instructions for } \\
\text { preparation }\end{array}$ & $\begin{array}{l}\text { Ministry of Health, } \\
\text { Central Statistical Office }\end{array}$ \\
\hline $\begin{array}{l}\text { Rb-Z, Rb-UZ, Rb-N, } \\
\mathrm{Rb}-\mathrm{UN} / \\
\text { Statement on the level } \\
\text { and structure of } \\
\text { liabilities }\end{array}$ & $\begin{array}{l}\text { Reports on receivables } \\
\text { and liabilities }\end{array}$ & $\begin{array}{l}\text { Regulation on the } \\
\text { statements of public } \\
\text { sector entities in the field } \\
\text { of financial operations }\end{array}$ & $\begin{array}{l}\text { Strictly regulated, certain } \\
\text { patterns, and principles } \\
\text { of preparation }\end{array}$ & $\begin{array}{l}\text { Ministry of } \\
\text { Finance/Ministry of } \\
\text { Health via founding } \\
\text { body }\end{array}$ \\
\hline $\begin{array}{l}\text { Budgetary } \\
\text { statements/Rb-WSa, } \\
\text { Rb-WSb }\end{array}$ & $\begin{array}{l}\text { The financial statements } \\
\text { of budgetary units and } \\
\text { other selected units }\end{array}$ & $\begin{array}{l}\text { Regulation on budget } \\
\text { reporting }\end{array}$ & $\begin{array}{l}\text { Strictly regulated, certain } \\
\text { patterns, and principles } \\
\text { of preparation }\end{array}$ & $\begin{array}{l}\text { Ministry of Finance via } \\
\text { founding body }\end{array}$ \\
\hline $\begin{array}{l}\text { The financial statement } \\
\text { on the fulfillment of the } \\
\text { contract for health care } \\
\text { services }\end{array}$ & $\begin{array}{l}\text { Information about the } \\
\text { level of fulfillment of a } \\
\text { contract with the NFZ, } \\
\text { an attachment to the } \\
\text { invoice for the payer }\end{array}$ & $\begin{array}{l}\text { Regulation on the scope } \\
\text { of the necessary } \\
\text { information collected by } \\
\text { service providers }(\ldots)\end{array}$ & $\begin{array}{l}\text { Certain patterns set out } \\
\text { in the agreement with } \\
\text { the payer public, } \\
\text { regulated deadlines for } \\
\text { preparation }\end{array}$ & $\begin{array}{l}\text { National Health Fund } \\
\text { (NFZ) }\end{array}$ \\
\hline $\begin{array}{l}\text { Financial plan/selected } \\
\text { elements of financial } \\
\text { reports/the level of } \\
\text { eligible liabilities }\end{array}$ & $\begin{array}{l}\text { Income, costs, and } \\
\text { financial results plan. } \\
\text { Value and age structure } \\
\text { of eligible liabilities }\end{array}$ & $\begin{array}{l}\text { Party: The act on the } \\
\text { medical activities }\end{array}$ & $\begin{array}{l}\text { Lack of specific } \\
\text { regulations }\end{array}$ & Founding body \\
\hline \multicolumn{5}{|c|}{ NON-FINANCIAL REPORTS } \\
\hline \multicolumn{5}{|c|}{ Reports on the provided health care services } \\
\hline $\begin{array}{l}\text { MZ-06, MZ-13, MZ-14, } \\
\text { MZ-24, MZ-35A, } \\
\text { MZ-54, MZ-55, } \\
\text { MZ/N-1a, MZ-Szp-11, } \\
\text { MZ/Szp-11B } \\
\text { MSW-34, MSW-35, } \\
\text { MSW-38, MSW-39, } \\
\text { MSW-42, MSW-44 }\end{array}$ & $\begin{array}{l}\text { Reports on the provided } \\
\text { health care services, by a } \\
\text { specific type }\end{array}$ & $\begin{array}{l}\text { The act on public } \\
\text { statistic; } \\
\text { regulation on } \\
\text { determining outlines of } \\
\text { reporting forms (...), } \\
\text { issued annually }\end{array}$ & $\begin{array}{l}\text { Established models and } \\
\text { deadlines for } \\
\text { preparation, selective } \\
\text { instructions for } \\
\text { preparation }\end{array}$ & $\begin{array}{l}\text { Ministry of Health, unit } \\
\text { for medical statistics } \\
\text { indicated by the regional } \\
\text { governor, Central } \\
\text { Statistical Office, } \\
\text { Ministry of the Interior, } \\
\text { other institutions }\end{array}$ \\
\hline $\begin{array}{l}\text { Waiting lists for health } \\
\text { care services/selected } \\
\text { data on } \\
\text { beneficiaries/patients }\end{array}$ & $\begin{array}{l}\text { The expected date of the } \\
\text { health care services; } \\
\text { selected information } \\
\text { abort health care } \\
\text { providers (as required) }\end{array}$ & $\begin{array}{l}\text { Regulation on the scope } \\
\text { of the necessary } \\
\text { information collected by } \\
\text { service providers }(\ldots)\end{array}$ & $\begin{array}{l}\text { Certain patterns of } \\
\text { waiting lists; lack of } \\
\text { specific } \\
\text { regulations-data } \\
\text { collected ad hoc, } \\
\text { according to the current } \\
\text { needs }\end{array}$ & $\begin{array}{l}\text { National Health Fund } \\
\text { (NFZ) }\end{array}$ \\
\hline
\end{tabular}


Table 3 continued

\begin{tabular}{|c|c|c|c|c|}
\hline Report's type/name & Report's field & Law regulation* & Scope of normalization & Stakeholder \\
\hline $\begin{array}{l}\text { Information about } \\
\text { provided health care } \\
\text { services }\end{array}$ & $\begin{array}{l}\text { The number of patients, } \\
\text { health services, the } \\
\text { length of stay, and the } \\
\text { number of death }\end{array}$ & $\begin{array}{l}\text { Lack of specific } \\
\text { regulations }\end{array}$ & $\begin{array}{l}\text { Lack of specific } \\
\text { regulations }\end{array}$ & Founding body \\
\hline \multicolumn{5}{|l|}{ Reports on resources } \\
\hline $\begin{array}{l}\text { MZ-88, MZ-89 } \\
\text { MSW-29, MSW-30 } \\
\text { Z-03, Z-06, and others }\end{array}$ & $\begin{array}{l}\text { Reports on available } \\
\text { resources and their use }\end{array}$ & $\begin{array}{l}\text { The act on public } \\
\text { statistic; } \\
\text { regulation on } \\
\text { determining outlines of } \\
\text { reporting forms }(\ldots), \\
\text { issued annually }\end{array}$ & $\begin{array}{l}\text { Established models and } \\
\text { deadlines for } \\
\text { preparation, selective } \\
\text { instructions for } \\
\text { preparation }\end{array}$ & $\begin{array}{l}\text { Ministry of Health, unit } \\
\text { for medical statistics } \\
\text { indicated by the regional } \\
\text { governor, Central } \\
\text { Statistical Office, and } \\
\text { Ministry of the Interior } \\
\end{array}$ \\
\hline $\begin{array}{l}\text { Reports on the utilization } \\
\text { of medical equipment, } \\
\text { employment of medical } \\
\text { personnel }\end{array}$ & $\begin{array}{l}\text { Reports on available } \\
\text { resources and their use }\end{array}$ & $\begin{array}{l}\text { Party and only } \\
\text { indirectly: The act on the } \\
\text { medical activities }\end{array}$ & $\begin{array}{l}\text { Lack of specific } \\
\text { regulations }\end{array}$ & Founding body \\
\hline \multicolumn{5}{|l|}{ Mixed reports } \\
\hline \begin{tabular}{|l|} 
MZ-11, MZ-15, MZ-19, \\
MZ-29, MZ-29A, \\
MZ-30, MZ-35B \\
MSW-32, MSW-33, \\
MSW-36, MSW-36A, \\
MSW-41, MSW-43, \\
MSW-45 \\
MS-ZK-7 \\
ZD-2, ZD-3, ZD-4, \\
ZD-5 \\
PS-03 \\
F-03 \\
PNT-01 i inne
\end{tabular} & $\begin{array}{l}\text { Reports on provided } \\
\text { health care services, by a } \\
\text { specific type, on } \\
\text { available resources and } \\
\text { other information; report } \\
\text { on the research and } \\
\text { development }\end{array}$ & $\begin{array}{l}\text { The act on public } \\
\text { statistic; regulation on } \\
\text { determining outlines of } \\
\text { reporting forms }(. . .) \text {, } \\
\text { issued annually }\end{array}$ & $\begin{array}{l}\text { Established models and } \\
\text { deadlines for } \\
\text { preparation, selective } \\
\text { instructions for } \\
\text { preparation }\end{array}$ & $\begin{array}{l}\text { Ministry of Health, unit } \\
\text { for medical statistics } \\
\text { indicated by the regional } \\
\text { governor, Central } \\
\text { Statistic Office, Ministry } \\
\text { of the Interior, and other } \\
\text { institutions }\end{array}$ \\
\hline $\begin{array}{l}\text { Investment plan, others, } \\
\text { and temporarily } \\
\text { established reports }\end{array}$ & $\begin{array}{l}\text { Plan of investment } \\
\text { expenditure }\end{array}$ & $\begin{array}{l}\text { The act on the medical } \\
\text { activities }\end{array}$ & $\begin{array}{l}\text { Lack of specific } \\
\text { regulations }\end{array}$ & Founding body \\
\hline
\end{tabular}

Notes. The main law regulations of Obligatory Reports Issued in health care sector in Poland are:

(1) the Act on the medical activity (2011, April), Journal of Laws 112, item 654 as amended; (2) the Act on Public Statistic (1995, June), Journal of Laws 88, item 439 as amended; (3) Regulation of the Minister of Finance on budget reporting (2014, January), Journal of Laws of 2014, item 119 as amended; (4) Notice of the Minister of Finance on announcing consolidated text of the Regulation of the Minister of Finance on the statements of public sector entities in the field of financial operations (2014, October), Journal of Laws of 2014, item 1773; (5) Notice of the Minister of Health on announcing of the consolidated text of the Regulation of the Minister of Health on the scope of the necessary information collected by service providers, the detailed method of recording this information and its submission to entities required to finance benefits from public funds (2013, July), Journal of Laws of 2013, item 1447; and (6) Regulation of the Prime Minister on determining outlines of reporting forms, explanations as to how to complete them, and outlines of questionnaires and statistical surveys used in statistical surveys defined in the program of official statistics for 2015 (2015, March), Journal of Laws of 2015, item 561.

Table 4

Type of Stakeholders of Mandatory Public Hospitals Reports

\begin{tabular}{|l|l|}
\hline \multirow{4}{*}{$\begin{array}{l}\text { Type of stakeholders of } \\
\text { mandatory public }\end{array}$} & Mandatory statistical reports \\
\cline { 2 - 2 } hospitals reports & - Founding body \\
& Central Statistical Office \\
& Ministry of Health \\
& - National Health Fund \\
& Local organizational unit designed by province governor for supervision of the health care sector \\
\hline
\end{tabular}




\section{The Information Scope of Reports Prepared for the Ownership Body by Public Hospitals}

As shown in last point, public hospitals carry out a number of reporting obligations. They cover both financial statements prepared under accounting law, budget reports drawn on the basis of budgetary law provisions, and statistical reports. There are also many recipients of these reports, representing different management levels.

Based on the nature of the conducted business activity, there can be distinguished the statistical medical and non-medical reporting. Table 3 shows the wide thematic variety, but also duplicated areas of the same issue addressed to different institutions. The information required for statistical reporting, in many cases, involves different business entities, which further hampers the identification of the reporting obligations relating to public hospitals. Table 4 shows the main recipient groups of hospital reporting.

The main recipient of statistical information in the field of health care is the Ministry of Health (Polish: Ministerstwo Zdrowia-MZ), which acquires it not directly, but through subordinate institution: the Centre for Health Information Systems (Polish: Centrum Systemów Informacyjnych Ochrony Zdrowia-CSIOZ). CSIOZ aggregates the individual statements from health care entities and collectively presents them to MZ. Another major recipient of statistical information provided by health care entities is the Central Statistical Office (Polish: Gtówny Urzad Statystyczny - GUS). In this case, there are clearly visible two reporting areas. The first concerns the reports submitted exclusively by health care entities and consisting mainly of factual information about the scope of provided health care services and pharmacy inventory turnover. The other range of information applies to virtually all entities of the national economy, among them health care entities. This range is not specialist in nature and is not directed at a particular industry. The group of ZD, F, PNT, PS, and Z submits the reports to the GUS according to Table 3.

The third major recipient of reporting data is the founding body of public health care entities. The supervision of health care entity is associated with the control of the accuracy and effectiveness of the entrusted founder's fund management and the achieved financial results as well as financial, material, and non-material consequences of these activities. It is the right and also the obligation arising from the investment of capital in certain projects. While in private entities the form, scope, and timing of exercising this supervision are not subject to specific reporting obligations, in the case of independent public health care facilities (e.g., public hospitals), this area is strictly regulated by law (Hass-Symotiuk, 2016).

From the provisions of the Act on Medical Activity (2011), result supervisory and controlling responsibilities of the ownership body with respect to the subordinate public hospital are in the following areas:

- the adoption and implementation of the financial plan and the investment plan of the hospital, which form the basis of its financial management;

- disposal of hospital's fixed assets, putting them in the lease, rental, granting usage, and lending rights;

- providing the assets of the public hospital or rights to them as an in-kind contribution to companies or their transfer to foundations or associations, which do not perform therapeutic activity;

- a legal act aimed at changing the creditor of the public hospital.

Reports submitted to the ownership body, which are also called control cards, due to the lack of legal provisions, can vary considerably in relation to various hospitals. Regardless of this differentiation, the following reporting areas can be distinguished:

- financial data, reported in the form of a complete or partial financial statement; 
- data on available resources and their management;

- data on the provided health care services;

- other ad hoc reporting areas (e.g., the effects of teaching, research).

The scope of the indicated first three thematic modules is presented in Table 5.

Table 5

The Scope of Reporting Areas to the Ownership Body of Public Hospitals

\begin{tabular}{|l|l|}
\hline Reporting area & Particulars \\
\hline Financial data & $\begin{array}{l}\text { Balance sheet data: fixed assets, current assets, own funds (including the financial result), liabilities, } \\
\text { and their detailed positions; }\end{array}$ \\
$\begin{array}{l}\text { Output data: presented usually in the form of profit and loss account, taking into account the detailed } \\
\text { breakdown of operating costs (e.g., the cost of use of different materials and energy, external } \\
\text { services, and salary titles) and particular business activity segments, e.g., operational, financing, and } \\
\text { charge on the financial result; }\end{array}$ \\
$\begin{array}{l}\text { - Supplementary data on maturing liabilities, including their title with the possible cascading due to } \\
\text { the maturity date. }\end{array}$ \\
$\begin{array}{l}\text { Data on the available } \\
\text { resources and their } \\
\text { management }\end{array}$ & $\begin{array}{l}\text { Information on employment, detailing professional groups and forms of employment, organizational } \\
\text { units, and average salary; }\end{array}$ \\
\hline $\begin{array}{l}\text { Information about medical equipment used, specifying the type, age, and possibly the number of } \\
\text { services performed; }\end{array}$ \\
$\begin{array}{l}\text { Information on planned investment purchases, broken down into fixed infrastructure (construction, } \\
\text { modernization, and refurbishment) and mobile infrastructure (purchase of medical equipment and } \\
\text { other fixed assets), as well as an indication of the source of funding and the planned completion date. }\end{array}$ \\
$\begin{array}{l}\text { The value of funding health care services during the contract period, the value of health care services } \\
\text { plan to execute in current contract and its implementation, services provided over the limit specified } \\
\text { in the contract, and breach of contract-by type of contracts and products; } \\
\text { Datalth on the provided } \\
\text { Delivery of services in the units of the core activity of the entity (wards, institutes, and clinics), } \\
\text { specifying: the type of entity contracted, the number of beds and places, number of hospital stays, } \\
\text { average length of stay, person-days, the number of consultations, degree of bed occupancy, number } \\
\text { and value of delivered services, income, expenses, and financial results of the unit; }\end{array}$ \\
$\begin{array}{l}\text { Inpatient structure, including coming from a given territory and from outside, broken down by units } \\
\text { of core activities. }\end{array}$
\end{tabular}

Source: Own study based on Hass-Symotiuk (2016).

The frequency of presenting information indicated in Table 5 is different, but no less frequent than once a year. In many cases, the reports are submitted in a simplified form every month and in a more extended form every quarter or every six months.

\section{The Impact of Behavioral Factors in Shaping Reporting Items of Public Hospitals}

The author's review of the detailed content of reports submitted by public hospitals to their ownership bodies helped to develop a list of the most important behavioral factors influencing the content of these reports. Among these factors, the followings can be indicated:

- interpersonal relationships;

- egoism;

- private financial interests;

- strengthening of the employment status and professional position;

- professional competences.

The selected factors are related to two levels of reporting processes. Most reports to the ownership body are based on internal reports prepared by lower levels of management in the health care entity. Typically, these are the units responsible for income and cost. Therefore, the indicated behavioral factors may occur in the 
reporting area on the level of the hospital management board - the owner (higher level) and the level of the subordinate organizational units - the management board of the hospital (lower level).

\section{Interpersonal Relationships}

In this regard, the causative agent is the degree of familiarity and sympathy, as well as the possible family connections and other factors. These phenomena are visible, especially in medical professionals. They can shape the desire of presenting related persons in a particularly advantageous manner, combined with less favorable and sometimes even negative presentation of the areas dependent on their potential competitors. In extreme cases, it may take a form similar to nepotism. These phenomena may affect the reporting of information about the cost level of external medical services and other costs (e.g., food costs, cost of hospital ward, laboratory diagnostics costs, level of use of hospital equipment and other diagnostic facilities, etc.). In this regard, for example, an adequate argumentation of the amount of costs is apparent, or the opposite- to omit them completely in the comments.

\section{Egoism}

This determinant is related to personality traits. It has been adopted as a particularly important feature of personality through which the rapporteur, protecting their person, affects the content of the reports. It can module at a higher level a desire to create the ideal image of the hospital manager in the eyes of its owner. Egoism can also take the form of unnecessary, harmful to the hospital, competition at a lower level. It may refer to heads of wards, or other units of medical and non-medical activities.

The areas of the shaped reporting items in large part focus on the core operations of the hospital. They may relate to over-/under-limit health care services, the degree bed occupancy, the number of inpatients, the level of costs incurred, and income generated, determining the average salary in various forms of employment, particularly of medical staff. There are also applied certain accounting policy instruments, for example, provisions for liabilities, including retirement benefits, change in depreciation rates, selected methods of balance sheet valuations of other assets and liabilities, and scope of inventory (e.g., omitting data on medications in hospital wards).

\section{Private Financial Interests}

Taking into account the principles of financing health care services in Poland, the followings should be indicated in this respect: aiming to over-/under-value the financial result of the hospital and its organizational units (e.g., molding of provisions, abandonment of write-downs, and postponement of income recognition). Such action allows to privatize the whole hospital or its part and ultimately to obtain financial and other benefits (also related to interpersonal relationships). Another factor is the link between employment in the public and private health care entity. It is observable in this case that a public hospital admits patients previously diagnosed in a private clinic. This involves shortening the waiting time for health care services and requires modification of the patient's medical records, which is the basis of the reports, e.g., in terms of waiting lists for health care services. Another example is the treatment, in public hospitals, of complications following health care services provided by the same medical staff in private units.

A wage policy in relation to the hospital's medical personnel (mostly physicians) and its biased justification of the submitted reports can also be indicated in this field. It may refer to concluded contracts for health care services and reporting information on their delivery, such action is mainly reflected in the level of costs, but also in the reports on the structure of resources and their use. 
Tools of behavior realization in this area are: provisioning policy, policy to make write-downs, method of fixed asset valuation, pursuit of over-limit health care services at the end of the reporting year (even unpaid), delaying deadlines for the recognition of documents in the accounting ledgers, ordering unnecessary medical tests for the utilization of the budget, or improving the efficiency of the other hospital unit (i.e., income, number of health care services performed, and ordering additional visits to the clinic).

\section{Strengthening of Employment Status and Professional Position}

This determinant is present on both levels of management, in a slightly different form. The head of the hospital concludes an appointment or managerial contract with the ownership body, which bears the features of the performance-related contract. The head is directly appraised on the implementation of the set objectives, which are partly defined at the recruitment stage by the appointee. This results in a desire to "window-dress" reports, particularly in the areas which are a subject to direct assessment. Possible behaviors relate to the repayment of outstanding debt at the balance sheet date, limitations on stock turnover and shifting deadlines for the recognition of documents in the accounting ledgers in order to present appropriately favorable information about assets and liabilities. Other examples include the manipulation of the data on the average length of hospital stay, place of the actual work of employees and place of their employment or shaping the scope of investment plans. Postponing the dates of concluding employment contracts, and the like, to the date falling after the report, as well as excessive shortening a patient's stay in the ward, is another example of the careful shaping of reporting items.

At the lower level, this determinant has all the characteristics of fulfilling the tasks assigned in the superior-subordinate relationship, including the achievement of the financial or other satisfaction (e.g., gaining trust of the superior, professional reputation, and of irreplaceable man). It appears that in this area, there may be a tendency to over-complicate reporting data and to exploit the freedom of data presentation in different elements of the same report.

\section{Professional Competences}

At a higher level - the lack of adequate preparation of the management board of the hospital in the field of financial accounting, referring the valuation of items of the balance sheet and profit and loss account (e.g., trade payables and other payables, receivables, fixed assets, and inventory) is noticeable. This problem can also affect the valuation of reserves. This factor may also influence the level of detail and transparency of data presented in the non-financial reports, for example, relating to the internal organizational units. The problem is compounded by the selection of medical professionals, not people with economic background, for directors of hospitals. Lack of qualifications in the management of an entity prevents adequate communication and verification of the correctness of data compiled by lower levels of management. Examples in this area apply to determining rates of remuneration of comparable jobs in different employment systems or to the justification of changes in income and costs elements presented in reports.

The above, as indicated, opens the way to shape specific reporting items presented by medical entities, in order to achieve the intended purpose. From the perspective of the top management, whose achievements are subject to reporting, apart from impulses of subjective nature, there should also be considered the ability to manage their own emotional state, their ability to admit mistakes, and the tendency to take risks. Moreover, the ability of top managers to manipulate and use the emotions of others to achieve their own goals is important in this context (Kent, 2006). 


\section{Results and Discussion}

As a result of the qualitative analyses of regulatory sphere and the scope of the sample reporting to the ownership body, the authors formulated the following issues for discussion:

- The behavioral factors selected for the analysis do not exhaust the list of possible ones, but only include those with the strongest impact, in the authors' opinion;

- Reporting of public hospitals to the ownership body is significantly burdened with behavioral factors and constitutes a field of intentional action of managers and hospital staff, particularly physicians;

- A deeper analysis of the identified issues shows that pathological situations, sometimes even abusive in terms of the legislation in force, must be separated from the effects of behavioral factors.

The information scope of the reporting prepared for the ownership body should have the top-down imposed level of detail. It should be kept in mind that too much information leads to misinformation, resulting in improper supervision. Only in certain cases, at the explicit request of the ownership body, additional reports must be submitted or supplementary annexes prepared.

\section{Conclusions}

Analysis of the literature points to a small number of studies on the behavioral aspects in reporting of public hospitals. Most publications relate to the behavioral problems of the general financial reporting, strictly regulated and, therefore, different from that presented in this paper.

The above-mentioned issues demonstrate a high simultaneous incidence of few behavioral factors, from those mentioned, in relation to shaping selected reporting items. It should be added, though, that the prime cause of these phenomena is the lack of sufficient regulation of the examined issues and the consequent substantial freedom in the reporting process. However, it has much more severe consequences for the management of the entire health sector. First of all, at the level of ownership bodies, poor-quality data about the financial and non-financial situation of health care entities are generated. Second, at the same level and also at a higher level, similar information is grouped, sometimes identical, but presented in a different form and time limits, and to another recipient. This results in the information chaos and excessive costs of obtaining information, as well as conflicting conclusions at times. In addition, the scope of the reporting is diametrically different at the various levels of public sector management. The growing level of sophistication at higher levels (regional and central) is visible in this respect. All these factors show the dysfunction of the reporting system of hospitals in Poland. Future work in this area should pursue the development of a uniform reporting model, which users will be stakeholders from different levels of health care system.

Behavioral factors in the reporting of public hospitals for ownership bodies have much greater importance than in other areas of reporting and other sectors of the economy. Their significant impact is due to many interests of the employees of hospitals, often their poor professional competence and complex interpersonal relationships. One of the reasons for this is the lack of a clear transparent vision of the ownership status of the health sector and, in part, their political dependence.

\section{References}

Christensen, T., Laegreid, P., \& Stigen, I. M. (2006). Performance management and public sector reform: The Norwegian hospital reform. International Public Management Journal, 9(2), 114-117.

Dziubińska, M., Janus, A., Kostrubiec, J., Sroka, T., \& Szczęśniak, P. (2014). Financing health care services. Warsaw: CeDeWu. 
Frączkiewicz-Wronka, A. (2001). The reform of the health care system in the perspective of integration with the European Union (The research papers of the University of Economics in Katowice, pp. 64-65).

Frolich, A., Talavera, J. A., \& Adams Dudley, R. (2007). A behavioural model of clinician responses to incentives to improve quality. Health Policy, 80(1), 179-193.

Hass-Symotiuk, M. (2010). The concept of hospital reporting for the integrated system of measuring performance. Szczecin: University of Szczecin.

Hass-Symotiuk, M. (2016). Reporting in health care entities (forthcoming). Warsaw: Wolters Kluwer Polska.

Holly, R., \& Suchecka, J. (2009). Public hospital in the Polish health care system. Lodz, Warsaw: The National Insurance Institute.

Kent, T. W. (2006). Leadership and emotions in health care organizations. Journal of Health Organizations and Management, $20(1), 49-66$.

Krivokapić, S. (2014). Characteristic of organizational leadership and motivation as a factor of change in the public health system. Chinese Business Review, 13(9), 586-597.

Krzeczewski, B. (2014). The impact of the founding body on financial effectiveness of hospitals from the region of Lodz (Financial markets, Insurance 65-University of Szczecin Scientific Papers No. 802, pp. 1-13).

McCleary, K., Rivers, P., \& Schneller, E. (2006). A diagnostic approach to understanding entrepreneurship in health care. Journal of Health and Human Services Administration, 28(3/4), 551-570.

Morris, S., Devlin, N., \& Parkin, D. (2011). Economy in health care. Warsaw: Wolters Kluwer Business.

Pettersen, I. J., \& Solstad, E. (2015). Vertical and horizontal control dilemmas in public hospitals. Journal of Health Organization and Management, 29(2), 185-199.

Porto, G., \& Lauve, R. (2006). Disruptive clinical behaviour: A persistent threat to patient safety. Patient Safety \& Quality Healthcare. Retrieved from psqh.com/julaug06/disruptive.html

Strojek-Filus, M., Szewieczek, A., \& Maruszewska, E. (2015). Reliability and faithful representation in the accounting theory-A literature review. Proceedings from SGEM 2015: 2nd International Multidisciplinary Scientific Conference on Social Sciences \& Arts SGEM 2015.

Szewieczek, A. (2014). Cost accounting system evolution in health care organizations-Current stage and the perspectives. Retrieved from http://www.ue.katowice.pl/uploads/media/11_A.Szewieczek_Cost_accounting_system....pdf 